[Original]

\title{
Risk Factors for Tuberculosis in an Urban Setting in Indonesia: A Case- control Study in Umbulharjo I, Yogyakarta
}

\author{
Sulistyawati SulistyaWati* and Andika Wisnu RamadHan \\ Faculty of Public Health, Universitas Ahmad Dahlan, Yogyakarta, Indonesia
}

\begin{abstract}
The rate of incidence of Tuberculosis (TB) in Indonesia is the ninth highest in the world. Poor environmental conditions, mainly related to air circulation and improper behaviour, were recognized as the risk factors in this country. A case-control study of 69 participants was conducted in the Umbulharjo I Public Health Centre of Yogyakarta during January-August 2019. Data collection was conducted using a tested questionnaire. Analysis was performed using Chi-square and Logistic regression. Three variables were identified as potential risk factors for TB: family history of TB, smoking behaviour, and ventilation condition. The results of the logistic regression test revealed that people who smoke have the greatest risk of TB infection. Health promotion needs to be enforced to educate both patients and their family to prevent the transmission of TB.
\end{abstract}

Keywords : Tuberculosis, risk factor, ventilation, smoking, Indonesia.

(Received May 18, 2020, accepted January 13, 2021)

\section{Introduction}

Tuberculosis (TB) is an infectious disease that receives attention globally. This disease is the top killer and produces the highest burden in many countries [1]. The World Health Organization reported that almost 5,000 people die of TB every day, $98 \%$ of whom live in developing countries, especially in the productive age [2]. As Indonesia has the second-highest burden of TB after India, Multi Drug-Resistant Tuberculosis (MDR-TB), Tuberculosis-Human Immunodeficiency Virus (TB-HIV), Tuberculosis-Diabetes Mellitus (TB$\mathrm{DM}$ ), and TB in children have become the focus of TB control there [3]. In 2017, 425,089 cases of TB were reported in Indonesia. This number was higher than the previous year, $2016(360,565)$ [3]. Most of the cases of TB in Indonesia occur in poor urban areas with a high population density [4].
The government of Indonesia developed a strategic plan to end TB in the period of 2016-2020. One strategy is to control the risk factors of TB [5], so monitoring the risk factors in society is essential to inform the policymakers for the development of the prevention program. Updating the TB risk factors will support the United Nations Sustainable Development Goals (SDGs) point 3, provide good health, and promote well-being [6]. The target of the SDGs is to reduce the TB mortality by $90 \%$ by 2030 [1], with milestones in 2020 and 2025 [7]. A previous review explored the potential risk factors for TB and categorized them into an environmental factor and host characteristics. The host characteristics include age, gender, immune status, malnutrition, alcohol consumption and smoking behaviour, diabetes, and occupation, while the environmental factors are population density and poor ventilation. Beyond that, the duration of proximity of

*Corresponding Author: Sulistyawati SulistyawaTI, Faculty of Public Health, Universitas Ahmad Dahlan, Yogyakarta, Indonesia, FKM UAD, $3^{\text {rd }}$ Campus of UAD. Jl Prof Dr Soepomo, Janturan, Umbulharjo, Yogyakarta, Indonesia. Tel: +62 8170402693, Fax: (0274) 564604, E-mail: sulistyawati. suyanto@ikm.uad.ac.id 
contact influences exposure to TB [8]. Urban settings, such as in Yogyakarta City, are the most frequently mentioned risk factors of possible infection of TB.

According to Indonesia's basic health research (2019), the number of TB cases in Yogyakarta province is categorized as low compared to the 34 other provinces [9]. There were 3,776 TB cases in Yogyakarta province in 2018. West Java province had the highest number of TB cases, with more than 90,000. The province with the fewest TB cases was West Papua, with 1,421 cases [10]. Yogyakarta province consists of five districts, and Yogyakarta City, which has been struggling with TB since about a decade ago, had the highest number of TB cases during 2013-2018. Figure 1 shows a comparison of the incidence rates of TB among the administrative levels in Yogyakarta province. It indicates that Yogyakarta City had the highest incidence rate in the district during three years of observation, even compared with the provincial rate [11]. Meanwhile, the TB cure rate in 2019 in the City of Yogyakarta was only $84 \%$, which was lower than the set target of $90 \%$. This means that TB in Yogyakarta City requires more attention in prevention efforts, including monitoring risk factors on an ongoing basis because of the high number of cases.

Recognizing and monitoring risk factors is essential to prevent the occurrence of the disease as well as for outbreak preparedness. Monitoring behavioural risk factors is used to measure TB infection in the population to consider prevention and control strategies. Several studies in the last decade have observed the risk factors of TB in Indonesia. One previous study mentioned that pulmonary TB is significantly associ-

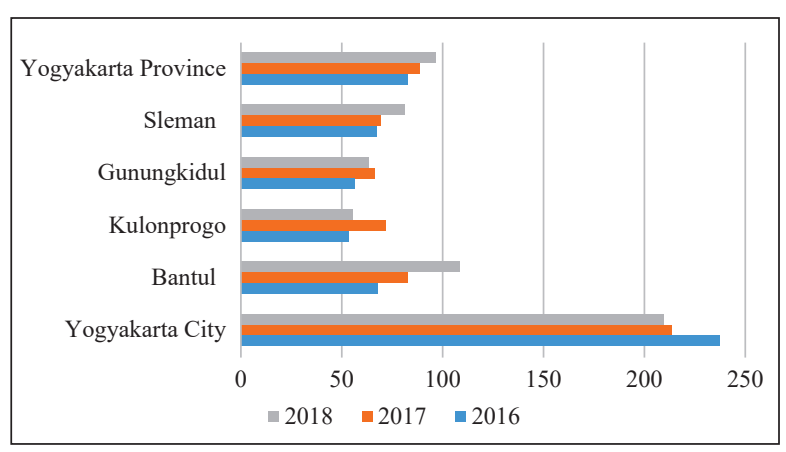

Figure 1. Comparison of TB incidence rates between district and province levels during 2016-2018. TB: Tuberculosis ated with gender, Diabetes Mellitus history, and contact history with TB patients [12]. A study in Kendal District, Central Java, found residential density, room temperature, indoor humidity, floor type, sputum placement, cough and sneeze habit as potential risk factors [13]. The two studies revealed that individual behaviour and the home environment are still potential risk factors for TB in Indonesia. Accordingly, to support the national TB plan in Indonesia and the SDGs 3 , it is essential to investigate the current potential risk factors for getting TB in both individual behaviour and the home environment. With this background in mind, the present research investigated the risk factors for TB from the home environment and behaviour using a case-control design in Umbulharjo of Yogyakarta, Indonesia.

\section{Materials and Methods}

\section{Study design and sample}

A case-control study with a 1:2 ratio between cases and controls, respectively, was conducted in Umbulharjo I Public Health Centre, Warungboto sub-district part of the City of Yogyakarta during September 2019. We used secondary data, which was the TB register in the Umbulharjo I Primary Health Centre (PHC). The case population was entirely TB patients who had taken medication during January-August 2019 in the Umbulharjo I Primary Health Centre (40 patients). The control population was all the citizens living in the Umbulharjo I PHC area who had been diagnosed as TB negative (58 patients). A sample calculation was conducted through Open Source Epidemiologic Statistics for Public Health (Bill and Melinda Gates Foundation, Seattle, USA) [14], by considering a 95\% confidence level, $80 \%$ of power, and Odds Ratio (OR $=5,618$ ) referred to in previous research [15]. Accordingly, this study involved 23 cases and 46 controls. Cases and controls were matched in sex and age.

The inclusion criteria for the cases were TB patients who had been diagnosed with pulmonary tuberculosis by a doctor through clinical examination and strengthened by a laboratory test. These patients had taken medication during January-August 2019, were aged 17-65 years old, were able to participate, and had resided in Umbulharjo for at least one year. The exclu- 
sion criteria for the cases were death of patient, cessation of medication, having multiple drug-resistant $\mathrm{TB}$, and extensively drug-resistant TB. The inclusion criteria for the controls were people who had resided in Umbulharjo for at least one year, being able to participate, and having had a TB test. The exclusion criteria for the controls were age below 17 years old and residing outside of Umbulharjo.

Among the 40 cases, 32 met the inclusion criteria. Among the 58 controls, 55 fit the inclusion criteria. Both for cases and controls, we systematically selected the participants starting from the newest cases until the number of samples was fulfilled.

\section{Research instrument}

We used two instruments: a questionnaire and a field measurements form. A structured questionnaire was used to collect the data from the participants. This questionnaire, which was adapted from previous research [16], was divided into 2 parts. Part 1 asked about respondent information and risk factors, such as name, address, age, education, status of residence, duration of residence, status of house renovation, and history of any family members of having TB. For education, we categorized as low when a respondent's highest level was graduation from junior high school. High education was when a respondent attended senior high school or upper education. Part 2 asked about behaviour: smoking and the duration. People who reported consuming at least one cigarette per day during a year were categorized as smokers. A non-smoker was a person who had not smoked for a minimum of one year. Lastly, the field measurement form was used to measure the house ventilation and bedroom ventilation by using a rolling meter. We categorized as adequate when they had ventilation of at least $10 \%$ compared to the total floor space [17-19]. The same ventilation requirement for residences has been used in Malaysia [20].

\section{Data collection}

Door to door visits were conducted to collect the data based on the sample list from the PHC. All of the respondents agreed to participate on the first visit. Activities were separated into two steps: interview and measurement. The interview was done face to face in Bahasa, Indonesia. For illiterate respondents, the questionnaire was read and filled in by the researcher (second author) based on their information. Informed consent was obtained before the interview.

\section{Statistical analysis}

Univariate analysis was used to calculate the distribution frequency. The risk factor was calculated using a chi-squares test by assessing the odds ratio and last conducted logistic regression with significance level $P$ $\leq 0.05$. The multivariate model was adjusted for sex, age and education. The calculation was executed in SPSS version 24.0 (IBM Corp., Armonk, NY, USA).

\section{Ethical consideration}

The study was approved by the Ethical review board of Universitas Ahmad Dahlan, Yogyakarta, Indonesia (ethical approval code: 011907068).

\section{Results}

A total of 69 respondents participated in this study, divided into 23 cases and 46 controls. The majority of the respondents were female and aged 17-45 years old or in the production phase. More than $70 \%$ of the respondents attended high school, meaning that they had not graduated from senior high school or attended university. Most of the respondents stated they did not have a family member with TB. Seventy-eight percent of respondents did not smoke. The majority of the respondents lived in houses that did not have adequate ventilation (Table 1).

In this study, the potential risk factors of TB we tested for were sex, age, education, history of family members with TB, smoking behaviour, and ventilation. Among them, three variables had a significant association with TB incidence at the $P \leq 0.05$ level: the history of family members having TB, smoking behaviour, and ventilation condition (Table 2). Having a family member who experienced TB increased the odds of someone getting TB infection by 4.59 times $(\mathrm{OR}=4.59)$. People who smoked one cigarette per day during one year increased the odds of getting $\mathrm{TB}$ infection by $4.28(\mathrm{OR}=4.28)$ times compared to those who did not. We found that people who lived in a house with poor ventilation conditions had 3.60 
Table 1. Socio demographic characteristics of the participants

\begin{tabular}{ll}
\hline Variable & N (\%) \\
\hline Sex & \\
Male & $29(42)$ \\
Female & $40(58)$ \\
Age (years old) & \\
$17-45$ & $49(71)$ \\
$>45$ & $20(29)$ \\
Education & \\
Low & $20(29)$ \\
High & $49(71)$ \\
Family history of TB & \\
Yes & $11(16)$ \\
No & $58(84)$ \\
Smoking behaviour & \\
Yes & $15(22)$ \\
No & $54(78)$ \\
Ventilation condition & \\
Not adequate & $41(59)$ \\
Adequate & $28(41)$ \\
\hline
\end{tabular}

Table 2. Bivariate analysis of $\mathrm{TB}$ incidence versus the potential risk factors

\begin{tabular}{lrrrr}
\hline Variable & \multicolumn{1}{l}{ TB } & P-Value & OR (95\% CI) \\
\cline { 2 - 3 } & Case N (\%) & Control N (\%) & & \\
\hline Sex & & & 0.66 & $1.42(0.51-3.91)$ \\
Male & $11(48)$ & $18(39)$ & & \\
Female & $12(52)$ & $28(61)$ & & \\
Age (years old) & & & 0.92 & $1.24(0.40-3.18)$ \\
$17-45$ & $17(74)$ & $32(70)$ & & \\
$>45$ & $6(26)$ & $14(30)$ & & \\
Education & & & 1.00 & $1.11(0.37-3.32)$ \\
Low & $7(30)$ & $13(28)$ & & \\
High & $16(70)$ & $33(72)$ & & \\
Family history of TB & & & 0.03 & $4.59(1.18-17.84)$ \\
Yes & $7(30)$ & $4(9)$ & & \\
No & $16(70)$ & $42(91)$ & & \\
Smoking behaviour & & & 0.03 & $4.28(1.29-14.21)$ \\
Yes & $9(39)$ & $6(13)$ & & \\
No & $14(61)$ & $40(87)$ & & \\
Ventilation condition & & & & \\
Not adequate & $18(39)$ & $23(50)$ & & \\
Adequate & $5(61)$ & $23(50)$ & & \\
\hline
\end{tabular}

$\mathrm{n}=69$, OR: odds ratio, 95\% CI: confidence interval, TB: Tuberculosis
Table 3. Multiple Logistic regression of risk factors for getting TB

\begin{tabular}{lccc}
\hline Variable & Adjusted OR* & $95 \%$ CI & $P$-value \\
\hline Family history of TB & 5.18 & $1.14-23.39$ & 0.03 \\
Smoking behaviour & 7.89 & $1.77-35.22$ & 0.00 \\
Ventilation condition & 6.69 & $1.55-28.81$ & 0.01 \\
\hline
\end{tabular}

$\mathrm{n}=69$, OR: odds ratio, $95 \%$ CI: confidence interval, TB: Tuberculosis, *adjusted for sex, age and education

$(\mathrm{OR}=3.60)$ times higher odds of getting TB infection compared to people who had adequate ventilation conditions.

In the multivariate analysis (Table 3), it was found that people who smoked were $7.89(\mathrm{OR}=7.89)$ times more likely to be infected by TB than those who did not smoke. Anyone who lived in poor ventilation condition was $6.69(\mathrm{OR}=6.69)$ times more likely to get TB infection. Lastly, those with a family history of TB were $5.18(\mathrm{OR}=5.18)$ times more likely to be infected by TB than those without a TB family history.

\section{Discussion}

Tuberculosis has received serious attention from the health authorities due to its contagiousness and high mortality rate. Monitoring TB's potential risk factors is essential for prevention purposes, especially in areas where TB becomes endemic or has a high incidence of cases. Individual, environmental, and behaviour variables are the main influences on the spread of TB in several regions of the world, including in Umbulharjo, an urban area in Yogyakarta.

Our research found that having a family member who experienced TB increased the risk (5.18 times) of someone getting TB infection. TB is transmitted directly to people by droplets from people infected with Mycobacterium tuberculosis [21, 22]. The microparticles are easily spread through the aerosol system. Thus, when a family member is positive for TB, it means an increased risk of other family members living in the same house getting TB because of the intensive interaction between them. The situation will be worse when they don't have sufficient air circulation in 
their house. This finding was confirmed by research in other countries such as Ethiopia and India [23, 24].

Smoking is a risk factor for the development of chronic obstructive pulmonary disease, lung cancer, and other respiratory diseases, especially TB [25], as has been proven by other research [26-28]. In our study, too, we found that smoking is a potential risk factor for TB. People who smoked one cigarette per day for one year had 7.89 times higher odds of getting TB infection than those who did not. Indeed, smoking is a big problem that coincides with the high population and the growth of the cigarette industry in Indonesia. In $2002,60 \%$ of adult males and $4 \%$ of females were smokers [29]. Smokers are found not only in the adult population but also among the youth. In 2018, $20 \%$ of youth aged $13-15$ years old were smokers, which was relatively high and could harm Indonesia in the future, related to the disease burden [30]. Accordingly, providing early education in health care and in school by using proper health promotion is essential. It can be face-to-face counselling, phone interaction, printed or electronic media, or internet sources [31].

We found that people who live in a house with poor ventilation conditions had 6.69 times higher odds of getting TB infection compared to people who have adequate ventilation conditions. It is well known that TB bacilli can survive in the air before being inhaled by a new host. Accordingly, the ventilation condition determines the transmission of TB in indoor environments related to free air circulation [32, 33]. In our research area, an urban setting, some of the residents built houses without a proper plan, resulting in the houses being huddled together with poor air circulation. Even if they have ventilation, they acquire insufficient fresh air inside their home. A similar situation was discovered in other parts of Indonesia [34, 35]. Seen from our results, there are bad circumstances where a house or settlement is already set up, making it difficult when they have to renovate their house to have better ventilation. A possible solution is to increase the penetration of the sunlight through the roof, since vitamin $\mathrm{D}$ is proven to improve immunity to TB [36, 37]. It is also important to have collaboration among government divisions such as health, infrastructure, and population to build proper new residences in the future.

This study has some limitations, such as the small sample, but we did our research in an urban area where there is a high incidence of TB. Accordingly, our sample may represent a bigger picture of TB in Yogyakarta and Indonesia.

\section{Conclusions}

In conclusion, we identified smoking behaviour as a possible risk factor for getting TB infection. The other risk factors are ventilation conditions and family history of TB. Therefore, it is important to improve knowledge, both formal and non-formal, targeting all segments of the population, to update the understanding of potential risk factors in society.

\section{Acknowledgement}

We would like to thank the TB programmer in Umbulharjo I PHC of Yogyakarta (Ibu MF. Rini W) for her assistance during the course of our research. We also wish to thank all the participants who contributed to this study.

\section{Conflict of Interest}

The author declares there is no conflict of interest.

\section{Funding}

This research did not receive any external funding.

\section{References}

1. WHO (2015): The End TB Strategy. World Heal. Organ. WHO, Geneva $16 \mathrm{pp}$ https://apps.who.int/iris/ handle/10665/331326 (accessed February 18, 2021)

2. WHO (2005): Tuverculosis control: surveillance, planning, financing. In: WHO report 2005. WHO, Geneva, $247 \mathrm{pp}$ https://apps.who.int/iris/bitstream/handle/ 10665/144569/9241562919_eng.pdf (accessed February 18,2021$)$

3. Ministry of Health Republic of Indonesia (2011): Health Profile of Indonesia. https://www.kemkes.go.id/ index.php?lg=LN02 (accessed January 20, 2020) (In Indonesia)

4. UNDP in Asia and the Pacific (2018): Defeating 
Drug-Resistant $\mathrm{TB}$ in Indonesia: A Human Face. https://medium.com/undp-in-asia-and-the-pacific/ defeating-drug-resistant-tb-in-indonesia-a-humanface-9d0ac70ee143 (accessed November 20, 2019)

5. Ministry of Health Republic of Indonesia (2018): Indonesia National TB Program Current status of integrated community based TB service delivery and the Global Fund work plan to find missing TB cases. https://www. who.int/tb/features_archive/indonesia_11 apr 18 . pdf?ua=1 (accessed February 19, 2021)

6. The United Nations. Health (2019): United Nations Sustainable Development. Available from: https://www. un.org/sustainabledevelopment/health/ (accessed November 20, 2019)

7. WHO(2019): Global Tuberculosis Report. https://www. who.int/publications/i/item/global-tuberculosisreport-2019 (accessed February 19, 2021)

8. Narasimhan P, Wood J, MacIntyre CR \& Mathai D (2013): Risk factors for tuberculosis. Pulm Med (2013) 828939

9. The Ministry of Health of Indonesia(2019): Main Results RISKESDAS 2018 (In Indonesian). http://kesmas. kemkes.go.id/assets/upload/dir_519d41d8cd98f00/ files/Hasil-riskesdas-2018_1274.pdf (accessed February 19,2021$)$

10. Ministry of Health of Republic of Inddonesia (2018): Data and information on Indonesia's Health profile 2018. https://www.kemkes.go.id/article/view/19041500003/ data-dan-informasi-profil-kesehatan-indonesia-2018. html (accessed February 19, 2021)

11. Yogyakarta Provincial Health Office (2019): Profile of Provincial Health Office of Yogyakarta. https://keseha tan.jogjakota.go.id/uploads/profil2019data2018.pdf (accessed February 19, 2021)

12. Padang IA \& Sudaryo MK (2019): A cross-secsional study: Analysis risk factors against pulmonary TB AFB positive in Indonesia. Indian Journal of Public Health Research and Development 10(2): 398-403

13. Wulandari AA, Nurjazuli \& Adi MS (2015): Risk factor and potential of transmission of tuberculosis in Kendal district, central Java. J Kesehat Lingkung Indones 14(1): 7-13 (In Indonesia)

14. Bill and Melinda Gates Foundation (2020): Open Source Epidemiologic Statistics for Public Health. https:www. openepi.com/SampleSize/SSCC.htm (accessed March 10, 2021)
15. Fitriani E (2013): Riskfactors related to the event of lung tuberculosis. Public Heal 2(1): 1-7 (In Indonesia)

16. Ayunah Y (2008): The relationship between factors of the quality of the physical environment of the home and the incidence of positive BTA Lung TB in the Cilandak District, South Jakarta in 2008. Thesis, Faculty of Public Health, University of Indonesia (In Indonesia)

17. Kurniawati E \& Sulistyorini L (2018): Analysis of the physical quality of the house with the presence of mycobacterium tuberculosis in the air. Indones J Public Heal 13(1): 13-24 (In Indonesia)

18. MInister of Health, Republic of Indonesia (2011): Indonesian Minister of Health Regulation No 1077/ Menkes/PER/2011. https://pkmgading.files.wordpress. com/2011/10/permenkes-pedoman-penyehatan-udaradalam-ruang-rumah.pdf (accessed February 19, 2021) (In Indonesia)

19. Indriyani N, Istiqomah N \& Anwar MC (2016): Relationship of humidity level of a households with the event of lung tuberculosis in the Tulis district region, Batang district. Unnes J Public Heal 5(3): 214

20. Nedhal AT, Sharifah FSF \& Adel A (2016): Relationship between window-to-floor area ratio and singlepoint daylight factor in varied residential rooms in Malaysia. Indian J Sci Technol 9(33): 1-8

21. Shiloh MU (2016): Mechanisms of mycobacterial transmission: how does Mycobacterium tuberculosis enter and escape from the human host. Futur Microbiol 11(12): 1503-1506

22. Mandal A (2019): Tuberculosis Transmission. News Med. Life Sci. https://www.news-medical.net/health/ Tuberculosis-Transmission.aspx (accessed November 19, 2019)

23. Shimeles E, Enquselassie F, Aseffa A et al (2019): Risk factors for tuberculosis: A case-control study in Addis Ababa, Ethiopia. PLoS One 14(4): e0214235

24. Andrews R., Devadatta S, Fox W, Radhakrishna D, Ramakrishnan C \& Velu S (1960): Prevalence of tuberculosis among close family contacts of tuberculous patients in South India, and influence of segregation of the patient on early attack rate. Bull World Health Organ 23(4-5): 463-510

25. Malin AS \& McAdam KP (1995): Escalating threat from tuberculosis: the third epidemic. Thorax 50 (Suppl): 1S37-42

26. Alavi-Naini R, Sharifi-Mood B \& Metanat M (2012): 
Association between tuberculosis and smoking. Int $\mathrm{J}$ High Risk Behav Addict 1(2): 71-74

27. den Boon S, van Lill SW, Borgdorff MW et al (2005): Association between smoking and tuberculosis infection: a population survey in a high tuberculosis incidence area. Thorax 60(7): 555-557

28. Borekci S, Duman B, Mazican N et al (2013): The relationship between smoking habit and tuberculosis in patients under anti-TNF- $\alpha$ treatment. European Respiratory Journal 42(Suppl 57): p4676

29. Aditama TY (2002): Smoking problem in Indonesia. Medical Journal of Indonesia 11(1): 56-65

30. Southeast Asia Tobacco Control Alliance (2018): Indonesia: Protecting Indonesian Youth From Tobacco. https://seatca.org/indonesia-protecting-indonesianyouth-from-tobacco/ (accessed November 20, 2019)

31. Harvey J, Chadi N \& Canadian Paediatric Society AHC (2016): Preventing smoking in children and adolescents: Recommendations for practice and policy. Paediatr Child Health 21(4): 209-221

32. Turner RD, Chiu C, Churchyard GJ et al (2017): Tuberculosis Infectiousness and Host Susceptibility. J
Infect Dis 216(suppl 6): S636-S643

33. Nagaraja SB, Satyanarayana S \& Bansal AK (2018): Can ventilation oust tuberculosis bacilli? Dare to plug the unpluggable. Public Health Action 8(1): 28

34. Rahayu SR, Katsuyama H, Demura M et al (2015): Factors associated with tuberculosis cases in Semarang District, Indonesia: case-control study performed in the area where case detection rate was extremely low. Environ Health Prev Med 20(4): 253-261

35. Sinaga FR, Heriyani F \& Khatimah H (2016): Relationship between house ventilation conditions and lung disease in the Kelayan Timur Health Center. Berk Kedokt 12(2): 279-288

36. Koh GC, Hawthorne G, Turner AM, Kunst H \& Dedicoat M (2013): Tuberculosis incidence correlates with sunshine: an ecological 28-year time series study. PLoS One 8(3): e57752

37. Wells WA (2006): Curing TB with sunlight. Journal of Cell Biology 172(7): 958a-958

J UOEH $43(2): 165-171(2021)$ 